\title{
Dostępność świadlczeń zurowotnych finansowanych ze środków publicznych w Polsce a funkcjonowanie sieci szpitali
}

\author{
Marcin Mikos ${ }^{1}$, Monika Urbaniak ${ }^{2}$
}

\author{
${ }^{1}$ Polskie Towarzystwo Prawa Medycznego \\ ${ }^{2}$ Zakład Prawa Medycznego, Uniwersytet Medyczny im. K. Marcinkowskiego w Poznaniu
}

Adres do korespondencji: Marcin Mikos, Polskie Towarzystwo Prawa Medycznego, 31-123 Kraków, ul. Krupnicza11A,mikos@ziz.com.pl

\section{Abstract}

\section{The impact of functioning of the hospitals network on availability of publicly funded health care services in Poland}

The article deals with the issue of access to health services financed from the public funds in Poland with regard to the so-called "network of hospitals" introduced on October 1, 2017. The network of hospitals is an instrument commonly applied for infrastructure planning, which is essential in providing patients with access to hospital treatment. The main purpose hereof is to present new legal solutions regarding the functioning of the hospital network in Poland in connection with ensuring access to healthcare services financed from the public funds for patients. The authors of the article made an attempt to assess whether the reform introducing the network of hospitals in Poland will contribute to the improvement of access to health services for patients and influence the increase of their health security. The above considerations are founded on the genesis and the concept evolution of the network of hospitals in Poland. The Polish experiences collected in the field mentioned above as well as the international experiences applied in selected European countries were presented herein. The network of hospitals functioning in Poland was analyzed in detail, and the authors indicated strengths and weaknesses thereof as well as existing and potential opportunities, and threats in its functioning.

Key words: availability of health care services, hospitals network

Slowa kuczowe: dostępność świadczeń zurowotnych, sieć szpitali

\section{Wprowadzenie}

Nadrzędnym zadaniem państwa w systemie ochrony zdrowia jest zapewnienie zasobów niezbędnych do jego funkcjonowania, umożliwienie równego dostępu do usług zdrowotnych oraz zabezpieczenie ich odpowiedniej jakości [1].

Polityka zdrowotna prowadzona przez poszczególne państwa znajduje odzwierciedlenie w wybieranych przez nie systemach opieki zdrowotnej, które mogą zarówno przybierać model jednocentryczny, cechujący się maksymalnym uregulowaniem jego cech przez państwo, wielocentryczny - zbliżony do mechanizmów rynkowych oraz pośredni między nimi - model pluralistyczny [2].
Niezależnie od modelu obranego przez polityków zdrowotnych w danym kraju Światowa Organizacja Zdrowia podkreśla, że wewnątrzkrajowa równość $\mathrm{w}$ zdrowiu oraz finansowanie ochrony zdrowia w ramach mechanizmów alokacyjnych opartych na zasadach równego dostępu do świadczeń zdrowotnych jest uniwersalnym celem każdego systemu zdrowotnego [3]. Natomiast miarą skuteczności systemów zdrowotnych jest ich rzeczywisty wpływ na poprawę stanu zdrowia objętych nimi populacji [4]. Zasoby każdego systemu zdrowotnego - to nie tylko kadra medyczna, lecz także odpowiednia infrastruktura i technologie medyczne. Do skutecznego i efektywnego funkcjonowania systemu niezbędne jest zatem optymalne zaplanowanie oraz wy- 
korzystanie posiadanych zasobów. Tworzenie sieci szpitali jest narzędziem planowania infrastruktury, która jest niezbędna w zapewnianiu dostępu do najbardziej wymagających usług w leczeniu pacjentów - do leczenia szpitalnego (stacjonarnego). $\mathrm{Z}$ tego też względu planowanie podaży usług medycznych, obok szacowania potrzeb zdrowotnych, opiera się na planowaniu rozwoju szpitali, w którym ich specjalistyczna struktura i rozmieszczenie terytorialne mają znaczenie podstawowe. Celem niniejszego opracowania jest przedstawienie nowych rozwiązań prawnych dotyczących funkcjonowania sieci szpitali w Polsce w kontekście zapewnienia dostępności świadczeń zdrowotnych finansowanych ze środków publicznych. Rozwiązanie w postaci sieci szpitali w polskim systemie zdrowotnym było dotychczas kilkukrotnie wykorzystywane.

W ramach modelu Siemaszki, który wprowadzono w Polsce po drugiej wojnie światowej, utworzono pierwszą w Polsce sieć szpitali, której podstawy funkcjonowania zawarte zostały w ustawie z dnia 28 października 1948 roku o zakładach społecznych służby zdrowia i planowej gospodarce w służbie zdrowia [5]. Pierwszą współczesną koncepcję krajowej sieci szpitali w Polsce przygotowano po roku 1997, a jej celem było stworzenie układu szpitali odpowiadającego rzeczywistemu zapotrzebowaniu na usługi medyczne oraz bardziej efektywne wykorzystanie istniejących zasobów [6]. Kolejna próba wprowadzania sieci szpitali w polskim systemie odbyła się w 2007 roku, projekt tej ustawy nie został jednak uchwalony przez parlament [7]. Obecnie krajowa sieć szpitali stanowi jeden z komponentów pakietu reformy ochrony zdrowia podjętej przez rząd wyłoniony po wyborach w 2015 roku. W dniu 1 października 2017 roku weszła w życie ustawa o zmianie ustawy o świadczeniach opieki zdrowotnej finansowanych ze środków publicznych, która stanowi podstawę prawną funkcjonowania sieci szpitali oraz finansowania szpitali metodą ryczałtową [8]. Celem artykułu jest porównawcza analiza koncepcji tworzenia krajowych sieci szpitali w Polsce na tle rozwiązań międzynarodowych w celu odpowiedzi na pytanie, w jakim stopniu koncepcja sieci szpitali zawarta w nowelizacji ustawy o świadczeniach opieki zdrowotnej finansowanej ze środków publicznych wpłynie na poprawę dostępności świadczeń zdrowotnych finansowanych ze środków publicznych. Analizie poddane zostały krajowe i międzynarodowe regulacje prawne, publikacje naukowe oraz raporty i dokumenty dotyczące funkcjonowania systemów zdrowotnych.

\section{Sieć szpitali jako narzęuzie regulacij podaży usług medycznych w krajach europejskich}

Planowanie sieci szpitali funkcjonuje w wielu krajach jako narzędzie regulacji przez państwa dostępu do publicznej ochrony zdrowia oraz administracyjnego wpływu na funkcjonowanie sektorów zdrowotnych. $Z$ wykorzystaniem sieci planuje się nie tylko samą podaż na świadczenia zdrowotne, lecz także odpowiadające jej zasoby w postaci kształcenia i zatrudnienia kadr medycznych, jak również infrastruktury niezbędnej do udzielania tych świadczeń.
Jednym z krajów o systemie zdrowotnym, w którym tradycja planowania strony podażowej w ochronie zdrowia sięga lat 60. XX wieku, jest Belgia. Planowanie sieci placówek medycznych, oparte na krajowym planie szpitalnictwa, finansowanym $\mathrm{z}$ budżetu narodowego, doprowadziło w tym kraju do restrukturyzacji placówek oraz ich konsolidacji, w konsekwencji czego doszło do redukcji liczby szpitali, a tym samym zmniejszenia liczby łóżek szpitalnych $[9,10]$. Podobny model planowania świadczeń medycznych funkcjonuje w Niemczech, gdzie corocznie na poziomie poszczególnych landów opracowywany jest plan szpitali, tak zwany Krankenhausplan, warunkujący to, czy dana placówka otrzyma finansowanie świadczeń zdrowotnych przez ubezpieczycieli [11]. Rezultatem wprowadzenia sieci w tym modelu była redukcja liczby łóżek szpitalnych i przesunięcie ciężaru opieki na rzecz placówek ambulatoryjnych, rehabilitacji oraz opieki długoterminowej [11]. Z kolei funkcjonujący we Francji model sieci szpitali sięga lat 40. XX wieku. Planowanie szpitali (publicznych i prywatnych) odbywało się na podstawie map medycznych, reglamentowania tworzenia nowych placówek medycznych oraz silnego modelu kontroli ze strony państwa. Ponieważ model ten - oprócz redukcji liczby łóżek szpitalnych doprowadził do marginalizacji aspektu jakości udzielanych świadczeń, jak również okazał się nieefektywny z punktu widzenia kontroli kosztów - został on zliberalizowany po 2000 roku i funkcjonuje, opierając się na regionalnych planach strategicznych współpracujących z sobą na rzecz kompleksowej opieki medycznej placówek szpitalnych [9]. Innym przykładem systemu zdrowotnego, w którym funkcjonuje publiczna sieć szpitali złożona z podmiotów o różnej strukturze właścicielskiej, jest system w Hiszpanii. Placówki w sieci zapewniają opiekę zdrowotną dla poszczególnych rejonów skupiających do 25000 mieszkańców [9]. Z kolei we Włoszech świadczenia opieki zdrowotnej udzielane w szpitalach znajdowały się pod ochroną władz publicznych. Na drodze licznych zmian ustawodawczych przeprowadzono reorganizację opieki zdrowotnej, której celem jest racjonalizacja sieci szpitalnej, między innymi poprzez obniżenie długości pobytu pacjenta w szpitalu oraz zmniejszenie liczby łóżek szpitalnych. Również w niektórych krajach postkomunistycznych, mimo ich rynkowej orientacji, stosuje się w sektorze zdrowotnym narzędzia planistyczne. Na przykład w Estonii od 2003 roku placówki medyczne funkcjonują, opierając się na planie tak zwanego rozwoju sieci szpitali, w ramach którego sporządzona została lista szpitali centralnych, regionalnych, ogólnych, lokalnych, specjalistycznych, rehabilitacyjnych oraz pielęgnacyjnych, działających $\mathrm{w}$ interesie publicznym i na tej podstawie mających możliwość otrzymywania pomocy ze strony państwa.

\section{Tworzenie sieci szpitali - doświadczenie polskie}

Pierwsza sieć szpitali w systemie zdrowotnym w Polsce ma związek z ustawą z dnia 28 października 1948 roku o zakładach społecznych służby zdrowia i planowej gospodarce w służbie zdrowia. Na jej podstawie, opie- 
rając się na zakresie profili medycznych oraz zasięgu geograficznym, funkcjonowały szpitale powiatowe, szpitale wojewódzkie, szpitale kliniczne, należące do grupy zakładów społecznej służby zdrowia utrzymywanych przez państwo. Artykuł 15 ust. 1 ustawy o zakładach społecznych służby zdrowia wprost posługiwał się pojęciem „sieci”, określając nim plan rozmieszczenia zakładów społecznej służby zdrowia ustalany przez ministra zdrowia. Ich finansowanie odbywało się na podstawie planu gospodarczego w zakresie służby zdrowia, z którego budżet państwa pokrywał wydatki zakładów społecznej służby zdrowia [5].

W demokratycznej Polsce próba wprowadzenia sieci szpitali pojawiła się po raz pierwszy w 1997 roku. Krajowa sieć szpitali miała zostać poprzedzona głęboką restrukturyzacją sektora zdrowotnego, ograniczeniem dowolności w gospodarowaniu zasobami opieki stacjonarnej, stworzeniem układu szpitali odpowiadającego rzeczywistemu zapotrzebowaniu na usługi medyczne, w tym w szczególności na zwiększenie liczby łóżek opieki długoterminowej i pielęgnacyjnej. Celem krajowej sieci szpitali było ponadto stworzenie warunków do racjonalizacji wydatkowania środków finansowych ponoszonych na utrzymanie stacjonarnej opieki zdrowotnej oraz bardziej efektywne wykorzystanie istniejących zasobów [6]. Koncepcja ta znalazła swój wyraz w nowelizacji ustawy z dnia 6 lutego 1997 roku o powszechnym ubezpieczeniu zdrowotnym, zgodnie $\mathrm{z}$ którą minister zdrowia uzyskał uprawnienia do określenia na drodze rozporządzenia krajowej sieci szpitali i oddziałów, ustalając ich poziom referencyjny w zależności od rodzaju udzielanych przez te szpitale świadczeń zdrowotnych (art. 31 c ust. 3). Wydane zostało Rozporządzenie Ministra Zdrowia i Opieki Społecznej z dnia 22 grudnia 1998 roku w sprawie krajowej sieci szpitali oraz ich poziomów referencyjnych (Dz.U. 1998 Nr 164, poz. 1193), zgodnie z którym do pierwszego poziomu referencyjności w krajowej sieci szpitali zakwalifikowano placówki posiadające oddziały chorób wewnętrznych, pediatrii, chirurgii ogólnej, ginekologii i położnictwa oraz anestezjologii i intensywnej terapii. Drugi poziom referencyjny obejmował szpitale wojewódzkie, udzielające świadczeń zdrowotnych w czterech podstawowych specjalnościach: chorób wewnętrznych, chirurgii ogólnej, położnictwa i ginekologii, pediatrii, a także z zakresu anestezjologii i intensywnej terapii oraz co najmniej w czterech z następujących specjalności: kardiologii, neurologii, dermatologii, patologii ciąży i noworodka, okulistyki, laryngologii, chirurgii urazowej, urologii, neurochirurgii, chirurgii dziecięcej i chirurgii onkologicznej. Z kolei trzeci poziom referencyjny obejmował szpitale kliniczne państwowych uczelni medycznych lub państwowej uczelni prowadzącej działalność dydaktyczną i badawczą w dziedzinie nauk medycznych oraz jednostki badawczo-rozwojowe podległe Ministrowi Zdrowia i Opieki Społecznej [12].

Wprowadzenie sieci szpitali w tym modelu spotkało się z krytyką między innymi ze strony samorządów lokalnych jako rozwiązanie ograniczające zadania szczebla samorządowego [13]. Także Najwyższa Izba Kontroli (NIK) wyraziła stanowisko, iż stworzenie krajowej sieci szpitali powinno zapewnić realizację zadań istotnych z punktu widzenia polityki zdrowotnej państwa oraz służy racjonalizacji rozmieszczenia szpitali na terenie kraju, umożliwiając efektywniejszą niż do tej pory realizację procesu restrukturyzacji. W ocenie NIK przynależność do sieci powinna być określona na podstawie przejrzystych, jednoznacznie określonych zasad, wykluczających możliwość arbitralnych decyzji co do umieszczenia zakładu w sieci lub jego wykluczenia [14]. W 2007 roku, po 8 latach funkcjonowania systemu ubezpieczeń zdrowotnych i kontraktowania świadczeń, została podjęta kolejna próba wprowadzenia regulacji prawnych dotyczących funkcjonowania sieci szpitali [7]. Celem tej inicjatywy było stworzenie z jednej strony narzędzia wyrównującego dostęp do świadczeń, a z drugiej - ograniczenie alokacji środków publicznych do podstawowego ich pakietu, uwzględniającego zróżnicowane potrzeby ludności. Inicjatywa ta poprzedzona została naukową prognozą zapotrzebowania na hospitalizacje w poszczególnych specjalnościach medycznych, opartą na analizie sytuacji zdrowotnej oraz demograficznej, przeprowadzonej przez Państwowy Zakład Higieny. Jednak projekt ustawy o sieci szpitali w tej wersji nie doczekał się zakończenia prac legislacyjnych i nie został uchwalony przez parlament.

\section{Założenia organizacij sieci szpitali w ustawie $\mathbf{2} 2017$ roku}

Pierwszym krokiem do tworzenia sieci szpitali było wprowadzenie w systemie zdrowotnym narzędzi koniecznych do planowania potrzeb zdrowotnych. W szacowaniu potrzeb zdrowotnych w systemie ochrony zdrowia w Polsce, podobnie jak w Wielkiej Brytanii czy Kanadzie, wprowadzone zostały sformalizowane narzędzia planistyczne w postaci map potrzeb zdrowotnych. Kwestie te reguluje ustawa o świadczeniach zdrowotnych finansowanych ze środków publicznych (dział IVA ustawy). Mapy potrzeb zdrowotnych tworzone są zarówno na poziomie regionalnym - wojewódzkim, jak i na poziomie centralnym na okres pięciu lat z koniecznością ich monitorowania oraz z możliwością ich aktualizowania. Analiza pierwszych ogólnopolskich map potrzeb zdrowotnych przygotowanych przez Ministerstwo Zdrowia dostarcza informacji o znaczących dysproporcjach występujących w dostępności ochrony zdrowia pomiędzy poszczególnymi województwami zarówno w określonych jednostkach chorobowych, jak i w poszczególnych specjalnościach medycznych [15]. W Tabeli I zamieszczone zostały przykładowe rekomendacje wynikające z ogólnopolskiej mapy zdrowotnej dla wybranych dziedzin leczenia szpitalnego.

Na poziomie wojewódzkim zadanie mapowania potrzeb zdrowotnych realizują poszczególni wojewodowie wraz z powołanymi przez nich gremiami doradczymi w postaci Wojewódzkich Rad do spraw Potrzeb Zdrowotnych, na podstawie danych epidemiologicznych, demograficznych oraz danych z rejestru podmiotów wykonujących działalność leczniczą. Na podstawie mapy regionalnej wojewoda ustala co roku priorytety dla regionalnej polityki zdrowotnej. Priorytety te powinny mieć odzwierciedlenie w kontraktowaniu świadczeń zdrowotnych przez publicznego płatnika. 


\begin{tabular}{|c|c|}
\hline Oddzial szpitalny & Wybrane rekomendacje \\
\hline Oddziały geriatrii & $\begin{array}{l}\text { W Polsce świadczenia do NFZ sprawozdawało } 38 \text { oddziałów geriatrycznych, z czego niemal } 30 \% \text { w woje- } \\
\text { wództwie śląskim. Jedynie dwa z oddziałów mają charakter ponadpowiatowy. Ze względu na to, że niemal } \\
\text { we wszystkich oddziałach są realizowane jedynie świadczenia, które można realizować na oddziałach chorób } \\
\text { wewnętrznych, należy rozważyć istnienie tych oddziałów w szpitalach powiązanych z uczelniami medycznymi. } \\
\text { Jednocześnie, ze względu na fakt przemian demograficznych, powinno się rozważyć wzmocnienie oddziałów } \\
\text { chorób wewnętrznych o specjalistów geriatrii. }\end{array}$ \\
\hline Oddziały diabetologii & $\begin{array}{l}\text { W Polsce świadczenia do NFZ sprawozdawało } 15 \text { oddziałów diabetologicznych, z czego najwięcej znajdowało } \\
\text { się w województwie mazowieckim. Znaczny odsetek świadczeń realizowanych na tym oddziale stanowią } \\
\text { świadczenia z zakresu choroby wewnętrzne. Jednocześnie obserwowana jest odwrotna relacja, to jest zakres } \\
\text { diabetologiczny stanowi istotny udział realizowany na oddziałach chorób wewnętrznych. Z tego względu } \\
\text { należy rozważyć możliwość pozostawienia oddziałów diabetologicznych jedynie w szpitalach powiązanych } \\
\text { z uczelniami medycznymi. Tezę tę wspiera dodatkowo fakt, że żaden z oddziałów nie miał charakteru ponad- } \\
\text { regionalnego (30\% pacjentów spoza województwa), a tylko jeden miał charakter wojewódzki (powyżej } 60 \% \\
\text { pacjentów spoza swojego powiatu). Wnioskuje się również rozważenie zwiększenia dostępności diagnozowania } \\
\text { i leczenia pacjentów w warunkach ambulatoryjnych lub jednodniowych. }\end{array}$ \\
\hline Oddziały toksykologii & $\begin{array}{l}\text { W Polsce świadczenia do NFZ sprawozdawało } 10 \text { oddziałów toksykologicznych, z czego dwa znajdowały się } \\
\text { w Krakowie. Tylko w trzech oddziałach udział specjalistycznych świadczeń zachowawczych (to jest świadczeń } \\
\text { możliwych do zrealizowania w analizowanym zakresie i równocześnie niemożliwych do zrealizowania na } \\
\text { oddziałach chorób wewnętrznych) przekroczył } 50 \% \text {. Na uwagę zasługuje również fakt, że jedynie dwa od- } \\
\text { działy miały charakter ponadpowiatowy (powyżej } 60 \% \text { pacjentów spoza powiatu), żaden nie miał charakteru } \\
\text { ponadregionalnego (ponad } 30 \% \text { pacjentów spoza województwa). Pozostałe oddziały zabezpieczały pacjentów } \\
\text { z własnego powiatu. Biorąc powyższe pod uwagę, należy rozważyć stworzenie koncepcji systemu leczenia } \\
\text { ostrych zatruć, opartego na ośrodkach ponadregionalnych. }\end{array}$ \\
\hline $\begin{array}{l}\text { Oddziały anestezjologii } \\
\text { i intensywnej terapii dla } \\
\text { dzieci }\end{array}$ & $\begin{array}{l}\text { W Polsce świadczenia do NFZ sprawozdawało } 38 \text { oddziałów anestezjologii i intensywnej terapii dla dzieci } \\
\text { (brak oddziału w województwie lubuskim). Należy również zauważyć, że oddziały te mają charakter głównie } \\
\text { powiatowy (powyżej } 60 \% \text { pacjentów z powiatu). Jedynie w przypadku jednego z nich można mówić o charak- } \\
\text { terze ponadregionalnym (ponad } 30 \% \text { pacjentów spoza województwa). }\end{array}$ \\
\hline
\end{tabular}

Tabela I. Przyktadowe rekomendacje dla wybranych dziedzin ochrony zdrowia wynikajace z map potrzeb zdrowotnych. Źródło: Opracowanie wtasne na podstawie Zakresu regulacji ustawy o sieci szpitali, Ministerstwo Zdrowia.

Zgodnie z obowiązkiem zawartym w ustawie dyrektor oddziału wojewódzkiego Narodowego Funduszu Zdrowia, sporządzając plan zakupu świadczeń opieki zdrowotnej na następny rok, uwzględnia mapę regionalną oraz stan dostępności świadczeń opieki zdrowotnej na obszarze danego województwa. Plan zakupu świadczeń opieki zdrowotnej składa się z:

- części ogólnej zawierającej w szczególności wskazanie priorytetów w zakresie finansowania świadczeń opieki zdrowotnej z uwzględnieniem priorytetów dla regionalnej polityki zdrowotnej wraz z uzasadnieniem;

- części szczegółowej określającej przede wszystkim obszary terytorialne, dla których przeprowadza się postępowania w sprawie zawarcia umów o udzielanie świadczeń opieki zdrowotnej, oraz maksymalną liczbę umów o udzielanie świadczeń opieki zdrowotnej, która zostanie zawarta na określonym obszarze, w danym zakresie lub rodzaju świadczeń.

Konieczność wprowadzenia sieci szpitali została uzasadniona przez rząd przede wszystkim wadą dotychczas funkcjonujących rozwiązań systemowych w postaci nieograniczonej możliwości ubiegania się o zawarcie umów o udzielanie świadczeń opieki zdrowotnej w zakresie leczenia szpitalnego i ambulatoryjnej opieki specjalistycznej przez wszystkie podmioty spełniające warunki określone dla danego profilu świadczeń w odpowiednich przepisach, wydanych na podstawie art. 31d ustawy z dnia 27 sierpnia 2004 roku o świadczeniach opieki zdrowotnej finansowanych ze środków publicznych. Zdaniem obecnego kierownictwa resortu zdrowia sytuacja ta utrudniała świadome i racjonalne kształtowanie właściwego zabezpieczenia dostępu do specjalistycznych świadczeń opieki zdrowotnej na poziomie szpitalnym i ambulatoryjnym, powodowała po stronie szpitali permanentny stan niepewności co do przyszłych warunków finansowania ich działalności, utrudniając racjonalną politykę inwestycyjną i długofalową politykę kadrową, a także przyczyniała się do marnotrawstwa ich zasobów, a w konsekwencji powodowała wydłużenie kolejki pacjentów oczekujących na świadczenia finansowane ze środków publicznych [15]. Powyższe wady, według rządu, uzasadniają wprowadzenie do systemu ochrony zdrowia zmian w organizacji i finansowaniu udzielania świadczeń zdrowotnych finansowanych ze środków publicznych.

Zgodnie z zamiarem ustawodawcy wprowadzenie sieci szpitali ma przynieść następujące skutki w systemie ochrony zdrowia:

- poprawę dostępu pacjentów do świadczeń specjalistycznych, w szczególności przez zapewnienie kompleksowości i koordynacji świadczeń ambulatoryjnych, szpitalnych i rehabilitacyjnych;

- zagwarantowanie odpowiedniego poziomu finansowania świadczeń realizowanych w szpitalach;

- zagwarantowanie ciągłości i stabilności finansowania jednostkom istotnym z punktu widzenia zabezpieczenia dostępu do świadczeń zdrowotnych przy równo- 
czesnym pozostawieniu możliwości dostępu do środków publicznych pozostałym jednostkom;

- zoptymalizowanie liczby oddziałów specjalistycznych.

Wprowadzony dzięki ustawie system podstawowego szpitalnego zabezpieczenia świadczeń opieki zdrowotnej ma zapewnić świadczeniobiorcom skoordynowany dostęp do świadczeń w zakresie leczenia szpitalnego, świadczeń wysokospecjalistycznych, ambulatoryjnej opieki specjalistycznej realizowanej w poradniach przyszpitalnych, rehabilitacji leczniczej, programów lekowych, leków stosowanych w chemioterapii oraz nocnej i świątecznej opieki zdrowotnej, przy jednoczesnym zagwarantowaniu ciągłości i kompleksowości udzielanych świadczeń oraz stabilności ich finansowania. Ustawa wprowadza sześć poziomów podstawowego szpitalnego zabezpieczenia świadczeń opieki zdrowotnej opartej na:

- szpitalach I stopnia;

- szpitalach II stopnia;

- szpitalach III stopnia;

- szpitalach onkologicznych lub pulmonologicznych;

- szpitalach pediatrycznych;

- szpitalach ogólnopolskich.

Każdy ze szpitali z danego poziomu opieki powinien posiadać ustawowo określone profile działalności medycznej (szpitalnej, ambulatoryjnej i rehabilitacyjnej), a także dodatkowe wymagania dotyczące prowadzonej działalności określone w Rozporządzeniu Ministra Zdrowia $\mathrm{z}$ dnia 13 czerwca 2017 roku w sprawie ustalenia szczegółowych kryteriów kwalifikacji świadczeniodaw- ców do poszczególnych poziomów systemu podstawowego szpitalnego zabezpieczenia świadczeń opieki zdrowotnej [16].

Nie sposób nie zauważyć, iż model podstawowego zabezpieczenia zdrowotnego stanowi powrót do integracji świadczeń zdrowotnych u jednego świadczeniodawcy, znany w Polsce z modelu organizacyjnego - zakładu opieki zdrowotnej, z którego zrezygnowano pod koniec lat 90. XX wieku. Nastąpiła wówczas separacja zintegrowanej dotychczas opieki specjalistycznej z opieką szpitalną, a także rozpoczął się proces częściowej prywatyzacji opieki ambulatoryjnej. Model opieki zintegrowanej w opinii wielu ekspertów zapobiega negatywnym zjawiskom, takim jak między innymi dezintegracja systemu i selekcjonowanie pacjentów [1].

Model podstawowego zabezpieczenia zdrowotnego powinien odpowiadać jednak rzeczywistym potrzebom zdrowotnym na danym obszarze opartym na diagnozie i prognozie wynikającej z map potrzeb zdrowotnych. Tymczasem przyjęta ustawa jednoznacznie i arbitralnie przewiduje, jakie profile działalności oczekiwane są od jednostek na poszczególnych poziomach opieki. Zakres ten jest w ustawie uogólniony dla wszystkich szpitali w Polsce bez uwzględnienia ewentualnych terytorialnych różnic i potrzeb (Tabela II). Posiadanie odpowiedniego zakresu świadczeń spowodowało więc niejako automatyczne zakwalifikowanie poszczególnych placówek medycznych, niezależnie od uwarunkowań geograficznej dostępności dla pacjentów czy też na przykład czynników jakości udzielanych świadczeń.

\begin{tabular}{|l|l|}
\hline \multicolumn{1}{|c|}{ Poziom leczenia } & \multicolumn{1}{c|}{ Oczekiwane profile zdrowotne w poszczególnych profilach } \\
\hline Szpitale I stopnia & $\begin{array}{l}\text { Chirurgia ogólna, choroby wewnętrzne } \\
\text { położnictwo i ginekologia, neonatologia } \\
\text { pediatria }\end{array}$ \\
\hline Szpitale II stopnia & $\begin{array}{l}\text { Chirurgia dziecięca, chirurgia plastyczna } \\
\text { Kardiologia, neurologia } \\
\text { Okulistyka. ortopedia i traumatologia narządu ruchu } \\
\text { Otolaryngologia, reumatologia, urologia }\end{array}$ \\
\hline Szpitale III stopnia & $\begin{array}{l}\text { Choroby klatki piersiowej (dorośli i dzieci), choroby płuc (dorośli i dzieci) } \\
\text { Choroby naczyniowe, choroby zakaźne (dorośli i dzieci) } \\
\text { Kardiochirurgia (dorośli i dzieci), kardiologia (dla dzieci) } \\
\text { Nefrologia (dorośli i dzieci), neurochirurgia (doróli i dzieci) } \\
\text { Okulistyka dla dzieci, ortopedia i traumatologii narządu ruchu dla dzieci, otolaryngologia dla dzieci } \\
\text { Toksykologia kliniczna (dorośli i dzieci), transplantologia kliniczna (dorośli i dzieci), urologia dla dzieci }\end{array}$ \\
\hline Szpitale onkologiczne & $\begin{array}{l}\text { Brachyterapia, ginekologia onkologiczna } \\
\text { Chemioterapia onkologiczna, hematologia } \\
\text { Onkologia i hematologia (dzieci) } \\
\text { Chirurgia onkologiczna (dorośli i dzieci) } \\
\text { Onkologia kliniczna, radioterapia } \\
\text { Terapia izotopowa, transplantologia kliniczna (dorośli i dzieci) }\end{array}$ \\
\hline Szpitale pulmonologiczne & $\begin{array}{l}\text { Chemioterapia - hospitalizacja } \\
\text { Chirurgia klatki piersiowej (doróli i dzieci) } \\
\text { Choroby płuc (dorośli i dzieci) }\end{array}$ \\
\hline Szpitale pediatryczne & Wszystkie profile szpitalne dla dzieci \\
\hline Szpitale ogólnopolskie & Wszystkie profile szpitalne \\
\hline
\end{tabular}

Tabela II. Podstawowe wymogi posiadania profili medycznych szpitali ubiegajacych się o wejście do tak zwanej sieci.

Źródto: Opracowanie własne na podstawie Ustawy z dnia 23 marca 2017 roku o zmianie ustawy o świadczeniach opieki zdrowotnej finansowanej ze środków publicznych (Dz.U. 2017 Nr 0, poz. 844) [8]. 
Oprócz głównych profili oczekiwanych od szpitali na poszczególnych poziomach referencyjności w ustawie zawarte zostały dodatkowe wymagania wejścia do sieci dla szpitali, a wśród nich między innymi wymóg dotychczasowego posiadania dwuletniego kontraktu na świadczenia w zakresie szpitalnego oddziału ratunkowego lub izby przyjęć, co pomimo zarzutu retroaktywności przepisu, jaki pojawił się na etapie sejmowego procedowania projektu, pozostało wymogiem obowiązującym we wprowadzonej ustawie. Katalog profili kwalifikujących szpitale do sieci nie wyczerpuje wszystkich zakresów świadczeń realizowanych obecnie przez placówki medyczne finansowane ze środków publicznych. Przykładem profilu świadczeń, którego obecność nie została wyeksponowana w ustawie, jest między innymi geriatria. Negatywne stanowisko w tej kwestii, podnoszące, że model sieci szpitali bez geriatrii narusza wytyczne Światowej Organizacji Zdrowia co do konieczności tworzenia oddziałów geriatrycznych jak najbliżej miejsca zamieszkania pacjentów w wieku podeszłym, bezskutecznie zostało zaakcentowane na etapie konsultacji społecznych [17].

Kwalifikacja szpitali do poszczególnych poziomów systemu zabezpieczenia jest dokonywana przez dyrektora wojewódzkiego oddziału Narodowego Funduszu Zdrowia raz na cztery lata. W ocenie ustawodawcy okres ten stanowi kompromis między potrzebą zapewnienia stabilizacji szpitalom a koniecznością dokonywania okresowej weryfikacji systemu, z możliwością jego poszerzenia o nowe podmioty. W praktyce oznacza to jednak brak możliwości wejścia do sieci nowo powstałych podmiotów leczniczych oraz elastycznego reagowania na pojawienie się nowych potrzeb zdrowotnych dla danej populacji na danym terenie. W ustawie brak jest też regulacji dotyczących możliwości rezygnacji placówki z obecności w sieci szpitali czy też wykreślenia placówki z sieci szpitali, na przykład z uwagi na zbiorowe naruszanie praw pacjenta czy też niską jakość świadczeń zdrowotnych, a także niespełnianie kryteriów bezpieczeństwa sanitarnego.

\section{Ksztaft sieci szpitali}

W 2017 roku do sieci szpitali zostały zakwalifikowane 594 placówki, z czego 516 to szpitale publiczne dysponujące bazą 145 tys. łóżek. Poza siecią pozostało 355 szpitali, w tym 16 placówek publicznych. Do poziomu szpitali I stopnia zakwalifikowano 283 placówki, a do szpitali II stopnia (realizujących bardziej skomplikowane świadczenia) - 96. Do szpitali III stopnia (wieloprofilowych szpitali specjalistycznych) zakwalifikowano 62 placówki.

W sieci znalazło się ponadto 20 szpitali onkologicznych, 30 pulmonologicznych, 13 pediatrycznych i 90 placówek ogólnopolskich (instytutów oraz szpitali klinicznych) [18]. Ustawa o sieci szpitali zagwarantowała zakwalifikowanym do niej placówkom medycznym finansowanie bez konieczności startowania w konkursach na świadczenia opieki zdrowotnej finansowe ze środków publicznych. Do szpitali zakwalifikowanych do sieci w IV kwartale 2017 roku przekazano 93\% całości środków zaplanowanych przez publicznego płatnika na leczenie szpitalne. Równolegle, obok sieci szpitali, publiczny płatnik wyłonił na drodze konkursu ofert świadczeniodawców, którzy wykonywać będą świadczenia zdrowotne uzupełniające zakres świadczeń wykonywanych przez placówki w sieci. Ponadto w niektórych dziedzinach, takich jak na przykład porody czy postępowanie w zawale serca, wprowadzony został jeszcze dodatkowy model finansowania świadczeń ze środków publicznych w ramach tak zwanej opieki koordynowanej.

\section{Dostepnosść świadczeń zdrowotnych w sieci w szpitali}

Dostępność świadczeń zdrowotnych może być zdefiniowana jako zabezpieczenie dostarczenia określonej populacji zdefiniowanego zakresu świadczeń medycznych, niezależnie od różnicujących kryteriów społecznych, ekonomicznych, kulturowych i geograficznych [19]. W założeniach ustawodawcy reforma wprowadzająca tak zwaną sieć szpitali ma przyczynić się do poprawy tak rozumianej dostępności świadczeń zdrowotnych dla pacjentów.

Czy jednak proponowana zmiana w systemie dotyka sedna tych problemów i ma szanse realnie wzmocnić system ochrony zdrowia oraz interesy i bezpieczeństwo jego użytkowników?

Przyjmując nowe rozwiązania w systemie ochrony zdrowia, ustawodawca powinien kierować się celem w postaci zwiększenia rzeczywistej dostępności świadczeń opieki zdrowotnej o określonym standardzie jakości, przynoszących oczekiwane rezultaty zdrowotne i czyniących ponoszone na to wydatki publiczne wydatkami efektywnymi. Wykładni konstytucyjnej gwarancji państwa zapewnienia obywatelom równego dostępu do ochrony zdrowia zawartej w art. 68 Konstytucji RP dokonał Trybunał Konstytucyjny, który stwierdził w jednym z orzeczeń, iż prawo obywatela do ochrony zdrowia nie może być prawem pozornym, ale sprowadza na organy państwa przyjmowanie takich rozwiązań, które zapewnią poszczególnym jednostkom realną możliwość korzystania z systemu ochrony zdrowia, funkcjonalnie ukierunkowanego na zwalczanie i zapobieganie chorobom, urazom i niepełnosprawności. Istotne znaczenie dla poprawy dostępności świadczeń zdrowotnych ma zwiększenie finansowania ochrony zdrowia oraz odpowiednia alokacja środków pozostających w dyspozycji sektora zdrowotnego. Dotychczasowe wzrosty nakładów na świadczenia zdrowotne były jednak za niskie w stosunku do rosnących potrzeb ludności oraz kosztów systemu. W konsekwencji nie następowała poprawa dostępności świadczeń, lecz zjawisko odwrotne w postaci wydłużania się kolejek oczekujących. Zwracali na to uwagę nie tylko eksperci, lecz także instytucje kontrolne (np. Najwyższa Izba Kontroli) [20].

W skutkach finansowych ustawy wprowadzającej sieć szpitali nie przewidziano na ten cel dodatkowych nakładów. Ponadto przyjęto założenia, że w pierwszym roku jej funkcjonowania szpitale znajdujące się w sieci otrzymają finansowanie na poziomie historycznego 
wykonania świadczeń zdrowotnych z roku 2015, co nie uwzględnia rosnącego zapotrzebowania na świadczenia zdrowotne wynikającego chociażby z potrzeb epidemiologicznych i demograficznych. Wypełnienie tej finansowej luki w systemie zdrowotnym nastąpiło w wyniku przekazania do systemu ochrony zdrowia w 2017 roku dodatkowych środków w wysokości $750 \mathrm{mln}$ zł na wybrane świadczenia zdrowotne, w tym między innymi na leczenie operacyjne zaćmy, endoprotezoplastykę biodra oraz diagnostykę radiologiczną. Dofinansowanie to miało jednak charakter doraźny i było możliwe dzięki dodatkowym oszczędnościom budżetowym.

Wątpliwości, czy organizacja świadczeń w sieci szpitali jest rozwiązaniem, które skróci kolejki oczekujących, już na etapie społecznych konsultacji projektu zgłosił między innymi prezes Narodowego Funduszu Zdrowia. Jego zdaniem, z związku z wprowadzeniem różnych rodzajów referencyjności szpitali, które będą się różniły zakresem świadczonych usług, konieczne jest zbudowanie od nowa modelu dostępu oczekujących do poszczególnych rodzajów świadczeń na określonym poziomie szpitali [21]. Negatywną ocenę możliwości poprawy dostępności świadczeń w sieci szpitali w debacie publicznej wyrażali także eksperci i politycy zdrowotni. Również w doświadczeniach międzynarodowych brak jest dostępnych publikacji dowodzących, iż wprowadzenie sieci szpitali ma znaczących wpływ na skrócenie kolejek pacjentów oczekujących na świadczenia zdrowotne. Takie przesłanki istnieją jednak, jeśli chodzi o wprowadzoną równolegle z siecią szpitali opiekę koordynowaną w zawale serca oraz porodach.

Samo oczekiwane przez ustawodawcę przesunięcie strumienia pacjentów z lecznictwa szpitalnego do ambulatoryjnej opieki specjalistycznej może być trudne do realizacji przede wszystkim z powodu deficytu kadry lekarskiej oraz długich kolejek oczekujących, które już występują w tym segmencie ochrony zdrowia.

W kontekście poprawy dostępności świadczeń zdrowotnych istotne znaczenie posiada także metoda finansowania świadczeń przez publicznego płatnika. W odniesieniu do wydatków publicznych efektywność finansowania rozpatrywana jest w kategorii maksymalizacji oczekiwanych skutków przy określonym poziomie finansowania bądź też jako minimalizacja nakładów finansowych w celu utrzymania określonych wyników [22]. Dominującym spojrzeniem na efektywność placówek medycznych jest ich mikroekonomiczna efektywność usługowa. Choć cel efektywności funkcjonowania sieci szpitali jest eksponowany w uzasadnieniu do ustawy o sieci szpitali, to jednak sposoby jego realizacji w nowym modelu organizacji i finansowania świadczeń zdrowotnych ze środków publicznych nie są dostatecznie wyartykułowane. Ustawodawca zdecydował o znaczącym ograniczeniu znaczenia dotychczas funkcjonującej metody finansowania świadczeń za usługi klasyfikowane według jednorodnych grup pacjenta (JGP) na rzecz ryczałtu. Model finansowania świadczeń w formie ryczałtowej niesie z sobą ryzyko mniejszej racjonalności i efektywności ekonomicznej w porównaniu z modelem rynkowego kontraktowania świadczeń.
W badaniach krajowych porównujących finansowanie szpitali w sposób podmiotowy (finansowanie budżetowe), w stosunku do zmiany na mechanizm przedmiotowy (za zrealizowane usługi), wykazano, iż mechanizm przedmiotowego finansowania przyczynia się do obniżenia „średniego czasu hospitalizacji” oraz do wzrostu wskaźnika ,przelotowości łóżek szpitalnych" [23]. W ryczałtowym finansowaniu świadczeń zdrowotnych nie występuje jednak dla płatnika problem finansowania ze środków publicznych ponadlimitowych świadczeń zdrowotnych. Ryczałt nie określa bowiem limitu świadczeń, a kwestia ta pozostaje w decyzji osób zarządzających podmiotami leczniczymi. Zmiana modelu finansowania świadczeń nie rozwiąże jednak proble$\mathrm{mu}$ zabezpieczenia rzeczywistych potrzeb zdrowotnych i czasu oczekiwania przez pacjentów na ich realizacje przez podmioty w sieci.

Skuteczniejsze rozwiązania w tym zakresie niż obecna ustawa wprowadzająca finansowanie budżetowe proponował projekt ustawy o sieci szpitali z 2007 roku. Zakładał on monitorowanie sytuacji finansowej szpitali w sieci na podstawie oceny ich sytuacji ekonomiczno-finansowej prowadzonej przy zastosowaniu analizy wskaźnikowej, opartej na wykorzystaniu następujących wskaźników:

- zyskowności - służącej do oceny efektywności działania szpitala;

- płynności - mierzącej zdolność szpitala do wywiązywania się z krótkoterminowych zobowiązań;

- efektywności - informującej, w jakich cyklach szpital spłaca zobowiązania, odnawia zapasy oraz otrzymuje należności z tytułu udzielania świadczeń opieki zdrowotnej;

- zadłużenia - informującego o zadłużeniu szpitala, jego strukturze oraz o zdolności szpitala do obsługi tego zadłużenia.

Szpitale o niskiej skuteczności i efektywności zarządzania świadczeniami, w projekcie autorstwa Zbigniewa Religii, nie mogły liczyć na pozostawanie w sieci. Artykuł 31 projektu tej ustawy przewidywał, iż w przypadku negatywnej oceny ekonomiczno-finansowej szpitali, poniżej określonych w projekcie progów ostrożnościowych, minister zdrowia z mocy ustawy był zobowiązany do wyłączenia szpitala $\mathrm{z}$ sieci szpitali z końcem roku kalendarzowego, w którym doszło do negatywnej oceny jego działalności, a na tej podstawie Narodowy Fundusz Zdrowia zaprzestawał przekazywania szpitalowi środków należnych z tytułu przynależności do sieci [4]. Takich rozwiązań brakuje w aktualnie obowiązującej ustawie o sieci szpitali, która nie przewiduje monitorowania sytuacji finansowej szpitali w sieci, a także wyłączenia szpitala z tej struktury. Choć oczywiście w przepisach powszechnie obowiązującego prawa istnieją parametry oceny finansowej publicznych szpitali (Rozporządzenie Ministra Zdrowia z dnia 12 kwietnia 2017 roku w sprawie wskaźników ekonomiczno-finansowych niezbędnych do sporządzenia analizy oraz prognozy sytuacji ekonomiczno-finansowej samodzielnych publicznych zakładów opieki zdrowotnej), to jednak sama ustawa o sieci szpitali nie wiąże finansowania z uzyskiwaniem 
przez placówki określonych rezultatów i będących ich miernikami wskaźników zdrowotnych, które miałyby konsekwencje dla obecności danej placówki w sieci. Następstwem zmiany finansowania świadczeń z kontraktowego na budżetowy, i to dla zamkniętego gremium świadczeniodawców, jakim jest sieć szpitali, jest wysokie ryzyko braku motywacji podmiotów leczniczych do zachowań konkurencyjnych, co z kolei może mieć bezpośredni wpływ na poziom jakości usług i bezpieczeństwo pacjenta. Stanowisko mówiące o tym, iż w takim kształcie ustawa o sieci spowoduje likwidację konkurencji na rynku usług zdrowotnych, na etapie konsultacji wyraził między innymi Urząd Ochrony Konkurencji i Konsumentów [24]. Skutkom tego typu ryzyk przeciwdziałały regulacje prawne proponowane $\mathrm{w}$ projekcie ustawy o sieci szpitali autorstwa Z. Religi, w której cały rozdział poświęcony był monitorowaniu i ocenie jakości świadczeń opieki zdrowotnej udzielanych przez szpitale włączone do sieci szpitali. Zakładał on między innymi obowiązek prowadzenia w tego typu szpitalach zarówno wewnętrznego systemu zarządzania jakością, jak i poddania szpitali sieciowych obowiązkowej zewnętrznej ocenie jakościowej opartej na parametrach, które zawiera Tabela III.

W tym wypadku negatywna ocena szpitala, jeśli chodzi o zarządzenie jakością, była podstawą do wyłączenia danej placówki z sieci szpitali i pozbawienia jej finansowania ze strony Narodowego Funduszu Zdrowia. W tym miejscu należy zauważyć, że podobne rozwiązania, w których poziom finansowania szpitali korygowany jest o określone współczynniki jakości, funkcjonuje z powodzeniem między innymi w Szwecji [9].

Ustawa o sieci szpitali w przyjętym kształcie wraz $\mathrm{z}$ aktami wykonawczymi premiuje finansowo jedynie sam fakt posiadania przez daną placówkę certyfikatu jakości oddziałów szpitalnych i laboratoriów, nie wnikając w cykliczne oceny parametrów jakości świadczeń, jak miało to miejsce w projekcie Z. Religi.

\section{Podsumowanie}

Jednym z najważniejszych i najbardziej złożonych wyzwań dla osób i instytucji odpowiedzialnych za ochronę zdrowia jest prawidłowe oszacowanie występujących obiektywnie potrzeb zdrowotnych, ich rozkładu terytorialnego, podziału na grupy społeczne czy też rodzaje schorzeń [1]. Niwelowanie zdiagnozowanych nierówności w dostępie do świadczeń zdrowotnych pozostaje głównym wyzwaniem dla systemu ochrony zdrowia, wynikającym zarówno z konstytucyjnej zasady równego dostępu do świadczeń zdrowotnych finansowanych ze środków publicznych, jak i z potrzeby implementacji i realizacji wyzwań europejskiej polityki spójności [12]. Szczególnie istotnym zadaniem pozostaje kwestia wyeliminowania terytorialnych różnic $\mathrm{w}$ dostępie do świadczeń zdrowotnych, wiążących się dla pacjentów zarówno z kosztami czasowymi, jak i niebezpieczeństwem opóźnienia czasowego pilnej interwencji medycznej, co może mieć negatywne skutki dla zdrowia [1]. Nadrzędnym celem skutecznych reform zdrowotnych jest rzeczywisty wzrost dostępności dla pacjentów świadczeń zdrowotnych finansowanych ze środków publicznych, pozwalający na wyrównanie różnic $\mathrm{w}$ dostępie i przynosząca zaspokojenie indywidualnych potrzeb oraz oczekiwań pacjentów [25]. Rozwiązania zawarte w ustawie wprowadzającej sieć szpitali, według ustawodawcy, zagwarantują odpowiedni poziom, a także ciągłość i stabilność finansowania szpitali, których funkcjonowanie jest niezbędne do zapewnienia pacjentom dostępności opieki zdrowotnej. Szpitale, spełniające kryteria kwalifikacyjne określone w ustawie i projekcie rozporządzenia, tworzą tak zwany system podstawowego szpitalnego zabezpieczenia świadczeń opieki zdrowotnej, na którego funkcjonowanie przeznaczono większość publicznych wydatków na zdrowie.

Reforma systemu ochrony zdrowia wprowadzająca sieć szpitali oraz ryczałtowe finansowanie świadczeń ze środków publicznych, pomimo zalet, budzi wiele py-

\begin{tabular}{|c|c|}
\hline Zakres & Parametry \\
\hline Struktura szpitala & $\begin{array}{l}\text { - } \text { organizacja szpitala } \\
\text { - } \text { kwalifikacje i kompetencje personelu } \\
\text { - } \text { stan techniczny budynków, pomieszczeń i wyposażenia } \\
\text { - } \text { wyposażenie w aparaturę i sprzęt medyczny }\end{array}$ \\
\hline Ocena leczenia & $\begin{array}{l}\text { - dostępność świadczeń opieki zdrowotnej } \\
\text { - } \text { zakres wykonywanych świadczeń opieki zdrowotnej } \\
\text { - } \text { relacja między personelem a pacjentem w zakresie stosowanych procedur diagnostycznych i leczniczych } \\
\text { - } \text { analiza ryzyka wysteppowania powikłań w zakresie stosowanych procedur } \\
\text { - } \text { występowanie i analiza zakażeń szpitalnych } \\
\text { - } \text { prowadzenie dokumentacji medycznej }\end{array}$ \\
\hline Rezultaty hospitalizacji & $\begin{array}{l}\text { - } \text { śmiertelność } \\
\text { - ponowne hospitalizacje } \\
\text { - } \text { reoperacje } \\
\text { - badania opinii pacjentów }\end{array}$ \\
\hline
\end{tabular}

Tabela III. Parametry jakości dla szpitali sieci wedlug projektu ustawy w wersji z 2007 roku.

Źródto: Opracowanie własne na podstawie Projektu ustawy o sieci szpitali z 2007 roku, źródło www.sejm.gov.pl, (dostęp: 11.06.2017) [7]. 


\begin{tabular}{|l|l|}
\hline $\begin{array}{l}\text { Mocne strony } \\
\text { obecność w sieci gwarantuje szpitalom ciągłość i stabilność } \\
\text { finansowania } \\
\text { premiowanie świadczenia usług kompleksowych przez jednostki } \\
\text { integracja świadczeń szpitalnych, ambulatoryjnych i rehabilitacji } \\
\text { mapowanie potrzeb zdrowotnych przez wojewodów i powiazanie } \\
\text { potrzeb z planami zakupu świadczeń }\end{array}$ & $\begin{array}{l}\text { Słabe strony } \\
\text { arbitralny kształt sieci narzucony przez ustawodawcę } \\
\text { obecność w sieci jedynie z uwagi na profil świadczonych usług } \\
\text { z pominięciem kwestii ich jakości, brak finansowania nadwyko- } \\
\text { nań świadczeń } \\
\text { wysokość ryczałtu uzależniona od historycznego wykonania } \\
\text { świadczeń }\end{array}$ \\
$\begin{array}{l}\text { Szanse } \\
\text { zawieranie umów na finansowanie na okres 4-letni } \\
\text { możliwość transferu pacjenta pomiędzy segmentami leczenia } \\
\text { zzpitalnego, ambulatoryjnego oraz rehabilitacji }\end{array}$ & $\begin{array}{l}\text { Zagrożenia } \\
\text { brak zainteresowania szpitali finansowanych ryczałtowo zwięk- } \\
\text { szaniem liczby wykowanych świadczeń zdrowotnych } \\
\text { ograniczenie konkurencyjności na rynku świadczeniodawców } \\
\text { medycznych } \\
\text { brak sankcji w postaci usunięcia jednostki z sieci szpitali } \\
\text { utrudnienia w dostępie do świadczeń dla pacjentów }\end{array}$ \\
\hline
\end{tabular}

Tabela IV. Analiza SWOT reformy wprowadzajacej sieć szpitali i zmiany w ich finansowaniu.

Źródto: Opracowanie własne.

tań, których weryfikacja może nastąpić jedynie dopiero w perspektywie czasowej. W Tabeli IV przedstawiono autorską analizę SWOT (Strengths, Weaknesses, Opportunities, Threats) wchodzącej w życie reformy systemu zdrowotnego.

\section{Wnioski}

1. Mapowanie potrzeb zdrowotnych w systemie ochrony zdrowia w Polsce na poziomie regionalnym i ogólnokrajowym jest działaniem pozytywnym i wymaga dalszego doskonalenia oraz wykorzystania do finansowania ze środków publicznych potrzebnych terytorialnie świadczeń zdrowotnych odpowiadających zdiagnozowanym potrzebom zdrowotnym.

2. Sieć szpitali jest w wielu państwach sprawdzonym narzędziem do planowania oraz restrukturyzacji zasobów ochrony zdrowia, dlatego jej wprowadzenie w systemie ochrony zdrowia w Polsce należy ocenić jako pozytywne rozwiązanie, z zastrzeżeniem, że kształt zaproponowany w znowelizowanej ustawie o świadczeniach zdrowotnych finansowanych ze środków publicznych wymaga zwiększenia elastyczności pod kątem realizacji celu poprawy terytorialnej dostępności świadczeń zdrowotnych finansowanych ze środków publicznych i zgodności z mapami potrzeb zdrowotnych określonych dla poszczególnych województw.

3. Wprowadzenie sieci szpitali w Polsce zwiększa znaczenie administracyjnego wpływu państwa na kształt systemu ochrony zdrowia, zmniejszając jednocześnie znaczenie mechanizmów rynkowych i konkurencyjnych oraz zbliżając kształt systemu zdrowotnego do modelu jednocentrycznego.

3. Kwalifikacja placówek w sieci szpitali jedynie z uwagi na profil świadczonych przez nie usług, bez określenia w ustawie konkretnych celów zdrowotnych, wskaźników wyrównania dostępności świadczenia oraz jakości i bezpieczeństwa pacjenta podlegających stałemu monitorowaniu, jak również brak sankcji w postaci wykreślenia placówki z sieci za naruszenie prawa pacjenta do bezpiecznej opieki medycznej, nie jest rozwiązaniem motywującym placówki medyczne do ciągłego zwiększania konkurencyjności oraz doskonalenia swojej działalności.

4. Oczekiwane po nowych rozwiązaniach prawnych: wzrost efektywności finansowania świadczeń zdrowotnych oraz poprawa dostępności świadczeń bez istotnego zwiększenia nakładów, dokonanie relokacji wydatków pomiędzy różnymi segmentami ochrony zdrowia, oparte na modelu budżetowym, należącym do najmniej efektywnych narzędzi finansowania, oraz brak finansowania tak zwanych nadwykonań, stawiają pod znakiem zapytania możliwość realizacji tych celów reformy.

\section{Piśmiennictwo}

1. Golinowska S., Od ekonomii do ekonomiki zdrowia, Wydawnictwo PWN, Warszawa 2016.

2. Włodarczyk W.C., Poździoch S., Systemy zdrowotne. Zarys problematyki, Wydawnictwo UJ, Kraków 2001.

3. Światowa Organizacja Zdrowia (WHO, World Health Organization), Health 21: The Health for All Policy Framework for the WHO European Region - 21 Targets for 21st Century, WHO, Copenhagen 1998.

4. Światowa Organizacja Zdrowia (WHO, World Health Organization), The World Health Report 2000. Health Systems: Improving Performance, Geneva 2000.

5. Ustawa z dnia 28 października 1948 roku o zakładach społecznych służby zdrowia i planowej gospodarce w służbie zdrowia (Dz.U. $1948 \mathrm{Nr}$ 55, poz. 434).

6. Murkowski M., Koronkiewicz A., Krajowy plan rozmieszczenia zakładów stacjonarnej opieki zdrowotnej. Projekt, Centrum Organizacji i Ekonomiki Ochrony Zdrowia, Warszawa 1997.

7. Projekt ustawy o sieci szpitali z 2007 roku, źródło www. sejm.gov.pl, (dostęp: 11.06.2017).

8. Ustawa $\mathrm{z}$ dnia 23 marca 2017 roku o zmianie ustawy o świadczeniach opieki zdrowotnej finansowanej ze środków publicznych (Dz.U. 2017 Nr 0, poz. 844).

9. Rusek A., Krajowa sieć szpitali jako narzędzie regulacji podaży w sektorze ustug medycznych, Uniwersytet Warszawski, Warszawa 2008. 
10. Kuszewski K., Krysińska M., Różycka A., Planowanie sieci szpitali. Historia pewnej inicjatywy, „Zeszyty Naukowe Ochrony Zdrowia. Zdrowie Publiczne i Zarządzanie" 2014; 12 (2): 129-133.

11. Wieczorkowska A., Nastęsstwa prywatyzacji szpitali w Niemczech, Uniwersytet Ekonomiczny we Wrocławiu, Wrocław 2012.

12. Busse R., Geissler A., Quentin W., Wiley M., Jednorodne grupy pacjentów w Europie, Europejskie Obserwatorium Polityki i Systemów Opieki Zdrowotnej, Narodowy Fundusz Zdrowia, Warszawa 2013.

13. Stanowisko z IV Zgromadzenia Ogólnego Związku Powiatów Polskich z dnia 12 kwietnia 2012 roku.

14. Najwyższa Izba Kontroli (NIK), Informacja o wynikach kontroli restrukturyzacji $i$ przekształceń systemowych w ochronie zdrowia, NIK, Warszawa 2004.

15. Ministerstwo Zdrowia (MZ), Uzasadnienie projektu ustawy o zmianie ustawy o świadczeniach opieki zdrowotnej finansowanych ze środków publicznych z dnia 26 września 2009 roku, www.legislacja.gov.pl (dostęp: 10.10.2017).

16. Rozporządzenie Ministra Zdrowia z dnia 13 czerwca 2017 roku w sprawie określenia szczegółowych kryteriów kwalifikacji świadczeniodawców do poziomów systemu podstawowego szpitalnego zabezpieczenia świadczeń opieki zdrowotnej, www.legislacja.gov.pl (dostęp: 10.10.2017).

17. Stanowisko Zarządu Głównego Kolegium Lekarzy Geriatrów w Polsce z dnia 25.10.2016, www.legislacja.gov.pl (dostęp: 10.10.2017).
18. Polska Agencja Prasowa, http://izba-lekarska.pl (dostęp: 11.06.2017).

19. Poździoch S., System zdrowotny, w: Zdrowie publiczne, Czupryna A., Poździoch S., Ryś A., W.C. Włodarczyk W.C. (red.), Vesalius, Kraków 2000: 127-128.

20. Najwyższa Izba Kontroli (NIK), Informacja o wynikach realizacji zadań Narodowego Funduszu Zdrowia w 2015 roku, NIK, Warszawa 2016.

21. Stanowisko Prezesa Narodowego Funduszu Zdrowia z dnia 31 października 2016 roku, www.legislacja.gov.pl (dostęp: 10.10.2017).

22. Peter-Bombik K., Kożuch A.J., Efektywne zarządzanie dtugiem jednostek samorzadu terytorialnego $w$ świetle obowiqzujacych regulacji prawnych, w: Frączkiewicz-Wronka A., Efektywność zarządzania organizacjami publicznymi i jej pomiar, „Studia Ekonomiczne. Zeszyty Naukowe Wydziałowe Uniwersytetu Ekonomicznego w Katowicach” 2013; 168: 245-255.

23. Wrona B., Działalność regulacyjna państwa $w$ sferze finansowania ochrony zdrowia, „Zeszyty Naukowe Ochrony Zdrowia. Zdrowie Publiczne i Zarządzanie" 2011; 11: 379-395.

24. Stanowisko Prezesa Urzędu Ochrony Konkurencji i Konsumentów z dnia 28.10.2017 roku, www.legislacja.gov.pl (dostęp: 10.10.2017).

25. Golinowska S., Raport. Finansowanie ochrony zdrowia w Polsce-Zielona Księga, Ministerstwo Zdrowia, Warszawa 2005 . 